\title{
PENGARUH PENGGUNAAN FERMENTASI DAN AMONIASI KULIT SINGKONG DALAM RANSUM TERHADAP PERTAMBAHAN BOBOT TUBUH DAN KONVERSI PAKAN PADA TERNAK DOMBA JANTAN
}

\section{The Effect of Using Fermented and Ammoniated Cassava Peel in the Ration on Body Weight Gain and Feed Conversion in Male Sheep}

\author{
Yuswan Jaya, Muhtarudin, Kusuma Adhianto, dan Erwanto \\ Department of Animal Husbandry Faculty of Agriculture Lampung University \\ Jl. Prof. Dr. Soemantri Brodjonegoro No. 1 Gedung Meneng Bandar Lampung 35145 \\ e-mail: jyuswan057@gmail.com
}

\begin{abstract}
This research intended to determine the effect of using fermented and ammoniated of cassava peel on body weight gain and feed convertion in male sheep. This research was conducted in June until August 2019 in a cage unit located in the Animal Husbandry Department, Agriculture Faculty, Lampung University. The research used Completely Randomized Design with 3 treatments and 3 replications. Experimental unit of this experiment were nine sheeps. The treatment used were P0 (Ration $+15 \%$ cassava peel without processing), P1 (Ration + fermented cassava peel), and P2 (Ration + ammoniated cassava peel). Variable in this study were feed intake, body weight gain, and feed conversion. The data obtained were analyzed for variance with significance level 5\%. The results showed that the use of fermented and amoniated of cassava peel was not significant $(\mathrm{P}>0,05)$ on feed intake, body weight gain, and feed conversion. Conclusion of this research is that fermented and ammoniated of cassava peel use in ration did not significantly increase body weight of sheep.
\end{abstract}

Key words: Amoniation, Body weight gain, Cassava peel, Feed convertion rate, Fermentation

Penelitian ini bertujuan untuk mengetahui pengaruh penggunaan kulit ubi kayu terfermentasi dan teramoniasi dalam ransum terhadap pertambahan bobot badan dan konversi pakan pada domba jantan. Penelitian ini dilakukan pada bulan Juni sampai dengan Agustus 2019 di unit kandang yang berlokasi di Jurusan Peternakan Fakultas Pertanian Universitas Lampung. Penelitian ini menggunakan Rancangan Acak Lengkap (RAL) dengan 3 perlakuan dan 3 ulangan. Unit percobaan ini adalah sembilan ekor domba. Perlakuan yang digunakan adalah P0 (Ransum $+15 \%$ kulit singkong tanpa pengolahan), P1 (Ransum + kulit singkong terfermentasi), dan P2 (Ransum + kulit singkong teramoniasi). Variabel dalam penelitian ini adalah konsumsi pakan, pertambahan bobot badan, dan konversi pakan. Data yang diperoleh dianalisis variansi dengan taraf signifikansi 5\%. Hasil penelitian menunjukkan bahwa penggunaan kulit ubi kayu fermentasi dan amoniasi tidak berpengaruh nyata $(\mathrm{P}>0,05)$ terhadap konsumsi pakan, pertambahan bobot badan, dan konversi pakan. Kesimpulan dari penelitian ini adalah bahwa penggunaan kulit singkong yang difermentasi dan diamoniasi dalam ransum tidak meningkatkan bobot badan domba secara signifikan.

Kata kunci: Amoniasi, Fermentasi, Konvesi pakan, Kulit ubi kayu, Pertambahan bobot badan

\section{PENDAHULUAN}

Limbah yang berasal dari industri singkong sangat potensial untuk digunakan sebagai pakan alternatif. Tanaman singkong merupakan tanaman yang memiliki banyak manfaat, mulai dari daun, batang dan umbinya. Umbi tanaman singkong atau sering disebut singkong, banyak digunakan sebagai bahan dasar pembuatan tepung tapioka, aneka makanan seperti keripik, getuk dan tiwul. Salah satu limbah hasil pertanian dan industri singkong yang dapat dimanfaatkan adalah kulit singkong. Kulit singkong sendiri memiliki porsi $16 \%$ dari tiap kilogram singkong. Lampung Tengah merupakan kabupaten utama penghasil ubi kayu di Provinsi Lampung dengan luas areal 130.781 ha, produksi 3,37 juta ton, dan produktivitas 25,78 t/ha (BPS Provinsi Lampung, 2013).

Kulit singkong memiliki potensi yang besar sebagai bahan pakan alternatif karena harganya murah, ketersediaannya banyak dan 
mudah didapat serta tidak bersaing dengan kebutuhan manusia. Kendala yang dihadapi dalam pemanfaatan kulit singkong adalah nilai nutrisinya yang rendah dan mengandung zat anti nutrisi sehingga perlu adanya proses pengolahan secara biologis (fermentasi) dan kimiawi (amoniasi) untuk meningkatkan nilai nutrisi dan menghilangkan zat anti nutrisi. Maynard dan Loosly (1979) menyatakan ukuran tubuh yang maksimal dan perkembangannya sangat ditentukan oleh genetik dan pengaruh lingkungan, terutama makanan sangat menentukan hasil akhirnya. Berdasarkan hal tersebut perlu dilakukan penelitian terkait pemanfaatan dan pengolahan kulit singkong sebagai pakan ternak domba dan pengaruhnya terhadap pertambahan bobot tubuh dan konversi pakan.

\section{MATERI DAN METODE}

\section{Materi}

Penelitian ini dilaksanakan selama 3 bulan di unit kandang Laboratorium Lapang Terpadu, Fakultas Pertanian, Universitas lampung.

Peralatan yang digunakan antara lain: kandang tipe individu, timbangan gantung, timbangan analitik, sekop, ember, terpal, cangkul, tong plastik dan karung.

Bahan-bahan yang digunakan antara lain: 9 ekor domba jantan, EM4, urea, kulit singkong terfermentasi dan teramoniasi, air, dan ransum (bungkil sawit, onggok basah, dedak halus, silase daun singkong, dan molases). Komposisi pemberian pakan dapat dilihat pada Tabel 1 .

Tabel 1. Komposisi Pemberian Pakan

\begin{tabular}{lccccc}
\hline \multirow{2}{*}{ Bahan pakan } & Komposisi & BK & As feed & Segar & Pemberian \\
\cline { 2 - 5 } & $(\%)$ & $(\%)$ & $(\%)$ & $(\%)$ & (kg/ekor/hari) \\
\hline Bungkil sawit & 15 & 88,6 & 16,93 & 5,28 & 0,08 \\
Onggok basah & 25 & 10 & 150,00 & 46,80 & 0,75 \\
Dedak halus & 16 & 88,82 & 16,89 & 5,27 & 0,08 \\
Daun singkong & 25 & 21,6 & 69,44 & 21,67 & 0,35 \\
Kulit singkong & 15 & 30,6 & 49,02 & 15,30 & 0,24 \\
Molases & 4 & 82,4 & 18,20 & 5,68 & 0,09 \\
\hline Jumlah & 100 & & 320,49 & 100 & 1,60 \\
\hline
\end{tabular}

Sumber : Fathul et al. (2015)

\section{Metode}

Penelitian ini dilakukan menggunakan Rancangan Acak Lengkap (RAL) dengan 3 perlakuan dan 3 kali ulangan. Rancangan perlakuan pada penelitian ini adalah

1. P0 : Ransum $+15 \%$ kulit singkong tanpa pengolahan

2. P1 : Ransum $+15 \%$ kulit singkong terfermentasi

3. $\mathrm{P} 2$ : Ransum $+15 \%$ kulit singkong teramoniasi

Peubah dalam penelitian ini yaitu:

A. Konsumsi : $\sum$ Pakan diberikan $-\sum$ Pakan tersisa

B. PBT : Bobot akhir - Bobot awal

Lama pengamatan

C. Konversi : Konsumsi

PBT

Data hasil penelitian dianalisis ragam dengan taraf 5\%.

\section{Pelaksanaan penelitian}

Tahap pertama meliputi pembuatan fermentasi kulit singkong dengan penambahan EM4 2\% dan pembuatan amoniasi kulit singkong dengan penambahan urea $3 \%$ dan masing-masing disimpan selama 21 hari. Tahap kedua pembuatan ransum basal dengan campuran silase daun singkong, onggok, dedak halus, bungkil kelapa sawit, dan molases.

Tahap persiapan pemeliharaan dilakukan dengan membagi kandang menjadi 9 bagian, pembersihan kandang, pemasangan alas tempat pakan, pemberian label pada kandang atau domba yang digunakan, dan pengadaan alat-alat pengambilan data.

Pemeliharaan dilakukan selama 74 hari dengan 14 hari prelium dan 60 hari pengamatan. Pakan domba diberikan pukul 07.00 WIB dan 17.00 WIB sesuai dengan kebutuhan dan perlakuan yang telah ditentukan. Penimbangan dan pencatatan sisa pakan dilakukan keesokan harinya.

Pengambilan data dilakukan dengan melakukan penimbangan bobot awal pada masing-masing domba, pengukuran konsumsi pakan selama 60 hari dengan cara menimbang pemberian dan sisa, dan menimbang bobot akhir domba.

\section{HASIL DAN PEMBAHASAN}

Rata-rata konsumsi, PBT dan konversi pakan dengan perlakuan pemberian fermentasi 
Tabel 2. Rekapitulasi Hasil Penelitian

\begin{tabular}{lccc}
\hline Parameter yang diamati & \multicolumn{3}{c}{ Perlakuan } \\
\cline { 2 - 4 } & $\mathrm{P} 0$ & $\mathrm{P} 1$ & $\mathrm{P} 2$ \\
\hline Konsumsi BK (gram/hari) & $622,45 \pm 16,58$ & $643,62 \pm 16,96$ & $666,52 \pm 38,93$ \\
PBT (gram/hari) & $71,89 \pm 17,72$ & $81,89 \pm 11,17$ & $91,83 \pm 16,28$ \\
Konversi pakan & $9,03 \pm 2,27$ & $7,94 \pm 0,92$ & $7,38 \pm 1,05$ \\
\hline
\end{tabular}

Keterangan : $\quad \mathrm{P} 0=$ Ransum $+15 \%$ kulit singkong tanpa pengolahan, $\mathrm{P} 1=$ Ransum $+15 \%$ kulit singkong terfermentasi, $\mathrm{P} 2=$ Ransum $+15 \%$ kulit singkong teramoniasi.

Tabel 2 menunjukkan bahwa pemberian perlakuan kulit singkong tidak memberikan pengaruh nyata $(\mathrm{P}>0,05)$ terhadap konsumsi, PBT dan konversi pakan domba selama pemeliharaan 60 hari. Hal ini menggambarkan bahwa pemberian perlakuan kulit singkong menimbulkan efek yang kecil pada tingkat konsumsi dan PBT serta konversi pakan pada domba jantan.

\section{Pengaruh Perlakuan terhadap Konsumsi BK}

Rata-rata konsumsi (Tabel 2) domba masing-masing perlakuan yaitu $622,45 \mathrm{~g}$ tanpa pengolahan (P0), 643,62 g fermentasi (P1), dan 666,52 g amoniasi (P2), hasil tersebut lebih rendah dibandingkan hasil penelitian Adhianto et al. (2019) konsumsi kambing dengan perlakuan $30 \%$ onggok terfermentasi mencapai $1.930 \mathrm{~g} / \mathrm{ekor} / \mathrm{hari}$. Hal ini diduga karena bobot ternak yang lebih rendah membuat ternak tersebut mengkonsumsi pakan yang lebih sedikit. Parakkasi (1999) menyatakan bahwa tingkat perbedaan konsumsi dipengaruhi oleh beberapa faktor antara lain faktor ternak (bobot tubuh, umur, tingkat kecernaan pakan, kualitas pakan dan palatabilitas). Arora (1989) menyatakan konsumsi BK pakan yang bermutu baik dapat mencapai 3,5\% (560 g) dari bobot tubuh $(16 \mathrm{~kg})$, sedangkan pakan bermutu rendah terbatas hanya $2 \%(320 \mathrm{~g})$ dari bobot tubuh (16 $\mathrm{kg}$ ).

Rataan konsumsi (Gambar 1) memperlihatkan peningkatan total konsumsi pada perlakuan fermentasi (P1) dan perlakuan amoniasi (P2) dibandingkan dengan tanpa pengolahan (P0), hal tersebut dapat disebabkan karena pengolahan pakan dengan fermentasi dan amoniasi diduga mampu meningkatkan kandungan protein pakan.

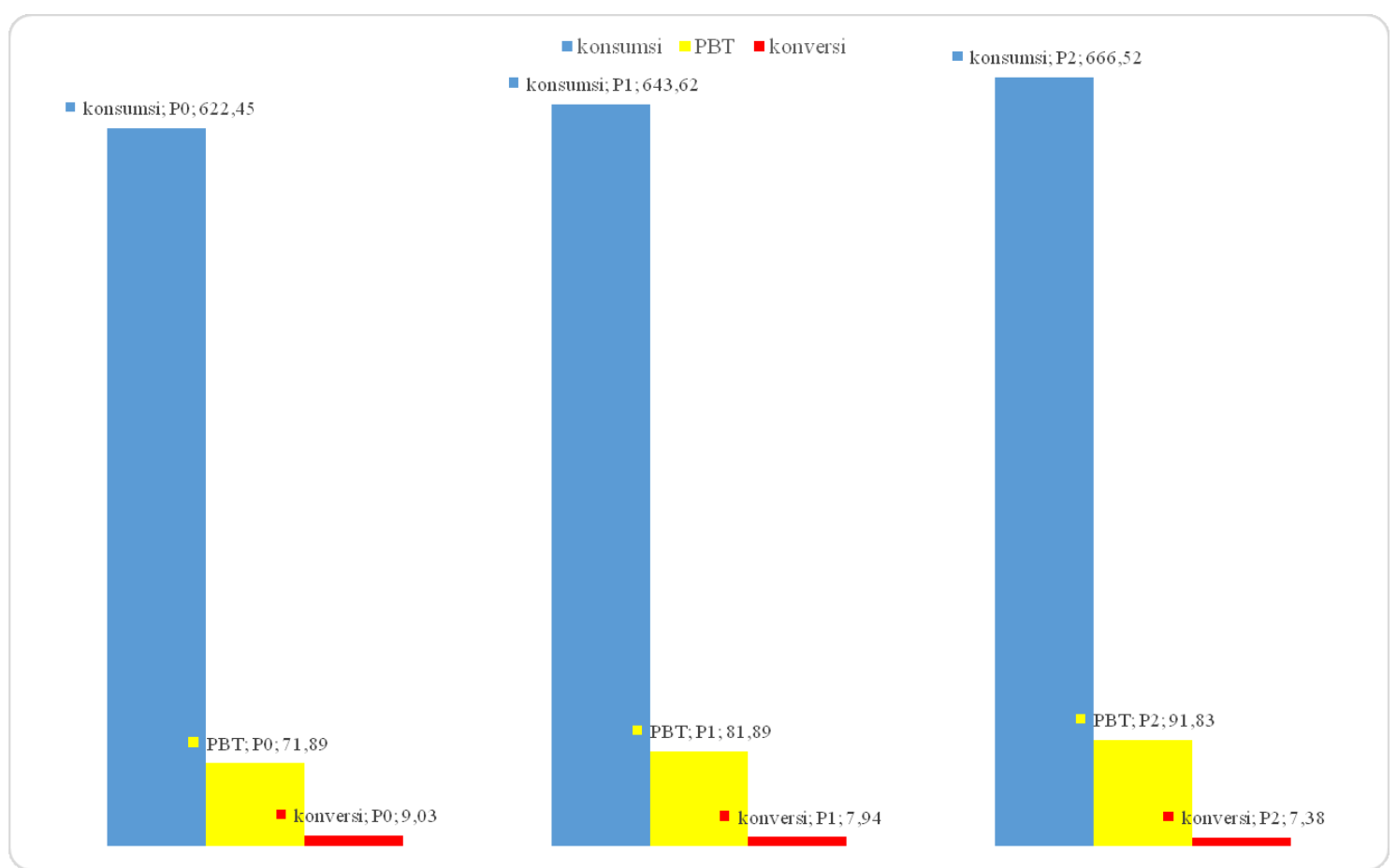

Gambar 1. Grafik rata-rata perhitungan hasil penelitian 
Berdasarkan hasil analisis di Laboratorium, kulit singkong tanpa pengolahan menghasilkan PK sebesar 4,08\%, perlakuan fermentasi sebesar $5,61 \%$, dan perlakuan amoniasi sebesar 9,24\%. Bamualim (1988) menyatakan bahwa kualitas pakan berpengaruh terhadap konsumsi. Hal ini juga dikemukakan oleh Parakkasi (1999) menyatakan bahwa tingkat perbedaan konsumsi dipengaruhi oleh beberapa faktor antara lain faktor ternak (bobot tubuh, umur, tingkat kecernaan pakan, kualitas pakan dan palatabilitas).

\section{Pengaruh Perlakuan terhadap Pertambahan Bobot Tubuh}

Rata-rata PBT (Tabel 2) masing-masing perlakuan yaitu $71,89 \mathrm{~g} /$ hari tanpa pengolahan (P0), 81,89 g/hari fermentasi (P1), 91,83 g/hari amoniasi (P2), dimana hasil tersebut tidak menunjukkan peningkatan yang signifikan pada perlakuan fermentasi dan amoniasi, hasil tersebut juga lebih rendah dari penelitian Adhianto et al. (2019) PBT kambing dengan perlakuan $30 \%$ onggok fermentasi mencapai $130 \mathrm{~g} / \mathrm{ekor} / \mathrm{hari}$. Hal ini diduga karena bobot tubuh yang lebih rendah membuat konsumsinya lebih sedikit sehingga pertambahan bobot tubuhnya lebih rendah. Kartadisastra (1997) menambahkan bahwa bobot tubuh ternak senantiasa berbanding lurus dengan konsumsi ransum, makin tinggi bobot tubuhnya, makin tinggi pula tingkat konsumsinya terhadap ransum. Prawoto et al. (2001) juga berpendapat rata-rata pertambahan bobot tubuh domba lokal yang dipelihara di peternakan rakyat berkisar 30 gram/hari, namun melalui perbaikan teknologi pakan (pakan komplit bentuk pellet) PBT domba lokal mampu mencapai 57-132 gram/ekor.

Peningkatan rata-rata PBT (Gambar 1) pada perlakuan fermentasi (P2) dan amoniasi (P3) diduga karena jumlah kandungan protein pakan yang meningkat sehingga nutrisi yang didapat oleh ternak lebih banyak. Sebagai pedoman kasar, jumlah protein kasar (PK) minimum yang diperlukan domba untuk hidup pokok sebesar $8 \%$ dari bahan kering. Domba yang sedang tumbuh atau laktasi memerlukan PK sejumlah 11\% dari BK (Gatenby, 1991). Pertambahan bobot tubuh dipengaruhi oleh beberapa faktor antara lain total protein yang diperoleh setiap hari, jenis ternak, umur, keadaan genetis, kondisi lingkungan, kondisi setiap individu dan manajemen tatalaksana (NRC, 1985). Warsiti et al. (2004) juga berpendapat bahwa laju pertumbuhan, kualitas dan kuantitas pakan, bobot tubuh merupakan faktor yang berhubungan erat antar satu dengan yang lain yang dapat mempengaruhi komposisi tubuh.

\section{Pengaruh Perlakuan terhadap Konversi Pakan}

Rata-rata konversi pakan (Tabel 2) pada masing-masing perlakuan yaitu 9,03 (P0) tanpa pengolahan, 7,94 (P1) fermentasi, dan 7,38 (P2) amoniasi, dimana hasil tersebut berada pada kisaran nilai standar (7--15) konversi pakan ternak domba. Konversi pakan merupakan jumlah pakan yang dikonsumsi untuk mendapatkan kenaikan satu satuan bobot hidup (Church, 1991). Konsumsi bahan kering yang rendah belum tentu menyebabkan konversi pakan yang tinggi sebaliknya konsumsi BK yang tinggi belum tentu menyebabkan konversi pakan yang tinggi, karena nilai konsumsi BK tergantung pada kualitas pakan dan PBT domba. Konversi pakan domba di daerah tropis berkisar antara 7 dan 15, artinya untuk menghasilkan 1 $\mathrm{kg}$ PBT dibutuhkan BK pakan sebanyak $7 \mathrm{~kg}$ (Purbowati et al., 2009).

Rataan konversi (Gambar 1) memperlihatkan pada perlakuan amoniasi (P2) memiliki nilai konversi yang lebih baik dibandingkan tanpa pengolahan (P0) dan perlakuan fermentasi (P1), hal ini terjadi karena kualitas dari pakan tersebut lebih tinggi diikuti pertumbuhannya lebih tinggi sehingga makin efisien penggunaan pakannya. Konversi pakan juga dipengaruhi oleh jumlah pakan yang dikonsumsi, bobot tubuh, gerak atau aktivitas tubuh, musim dan suhu dalam kandang. Semakin baik kualitas pakan yang dikonsumsi ternak, maka akan diikuti dengan pertambahan bobot tubuh yang lebih tinggi dan makin efisien penggunaan pakannya (Pond et al., 1995).

\section{KESIMPULAN}

Berdasarkan penelitian yang telah dilakukan dapat disimpulkan bahwa penggunaan fermentasi dan amoniasi kulit singkong tidak signifikan meningkatkan konsumsi, pertambahan bobot tubuh, dan konversi pakan ternak domba.

\section{DAFTAR PUSTAKA}

Adhianto, K., Muhtarudin, A. Husni, dan F. Zhahir. 2019. Pengaruh pemberian limbah singkong terfermentasi dan mineral mikro organik dalam ransum 
terhadap penampilan kambing. Sains peternakan $17(2): 12--16$

Arora, S. P. 1989. Microbial Digestion in Ruminansia. Indian Council of Agricultural Reserch. New Delhi. Terjemahan: Pencernaan Mikroba pada Ruminansia. Edisi Indonesia, oleh : Muwarni, R. Editor: Srigandono, B. Fapet. Gadjah Mada University Press.Yogyakarta.

Bamualim, A. 1988. Prosedur dan Parameter dalam Penelitian Pakan Ternak Ruminansia dalam Prinsip Produksi dan Penelitian Peternakan. Kumpulan Materi Kursus Sub Balai Penelitian Ternak Lili. Kupang.

Badan Pusat Statistik Provinsi Lampung. 2013. Lampung dalam Angka 2013. BPS Provinsi Lampung. Lampung.

Chruch, D. C. 1991. Digestives Physiologi and Nutrition of Ruminants. Oregon State University Press, Corvallis. Oregon.

Fathul, F., Liman., N. Purwaningsih, dan S. Tantalo, Y. S. 2015. Pengetahuan Pakan dan Formulasi Ransum. Universitas Lampung. Lampung.

Gatenby, R. M. 1991. The Tropical Agriculturalist Sheep. 1st Edition. Mc Millan Education Ltd. London and Basingtone.

Kartadisastra, H. R. 1997. Penyediaan dan Pengolahan Pakan Ternak Ruminansia. Kanisius. Yogyakarta.

Maynard, L. A. and J. K. Loosly. 1979. Animal Nutrition. Fourth Edition. McGrow-/Hill Book Company, Inc. New York.
National Research Council. 1985. Nutrient Requirement of Sheep. 6th Revised Edition. National Academy Press. Washington.

Parakkasi, A. 1999. Ilmu Nutrisi dan Makanan Ternak Ruminansia. Universitas Indonesia Press. Jakarta.

Pond, W. G., D. C. Church, and K. R. Pond. 1995. Basic Animal Nutrition and Feeding. John Wiley and Sons Press. New York.

Prawoto, J. A., C. M. S. Lestari, dan E. Purbowati. 2001. Keragaan dan kinerja produksi domba lokal yang dipelihara secara intensif dengan memanfaatkan ampas tahu sebagai bahan pakan campuran. J. Pengembangan Peternakan Tropis Special Edition : 277--285.

Purbowati, E., C. I. Sutrisno, E. Baliarti, S. P. S. Budhi, W. Lestariana, E. Rianto, dan Kholidin. 2009. Penampilan Produksi Domba Lokal Jantan dengan Pakan Komplit dari Berbagai Limbah Pertanian dan Agroindustri. Prosiding. Seminar Nasional Kebangkitan Peternakan. Semarang. (1) : 130--138.

Warsiti, T., I. W. S. Dilaga, dan M. Arifin. 2004. Perkembangan komposisi tubuh domba pada berbagai fase pembesaran berdasarkan metode urea space. $J$. Pengembengan Peternakan Tropis 2(9) : 188--193 